\title{
PENGEMBANGAN PEMBELAJARAN SEJARAH MELALUI MODEL PEMBELAJARAN LIVING HISTORY UNTUK MEMBENTUK NASIONALISME PESERTA DIDIK
}

\author{
Sahit Sulaiman \\ Program Studi Pendidikan Sejarah FKIP universitas lambung mangkurat \\ Banjarmasin \\ Email : sahitsulaiman8@gmail.com
}

\begin{abstract}
Abstrak
Sikap nasionalisme sangat erat kaitannya dengan sejarah maka dari itu pembelajaran sejarah harus dapat memberikan kontribusi dalam pembentukan sika nasionalisme maka dalam pembelajaran menggunakan model living history.

Model Model Pembelajaran Living History merupakan model pembelajaran sejarah yang bersumber pada lingkungan kehidupan sekitar siswa. Model Pembelajaran Living History membimbing peserta didik dalam melakukan penelusuran peristiwa sejarah yang terdapat di lingkungan sekitarnya, tempat peserta didik menjalani kehidupan kesehariannya.
\end{abstract}

Kaka kunci : nasionalisme, pembelajaran sejarah dan model living history.

\section{Pendahuluan}

Sejarah digambarkan sebagai masa lalu manusia dan seputarnya yang disusun secara ilmiah dan lengkap meliputi urutan fakta masa tersebut dengan tafsiran dan penjelasan yang memberi pengertian dan kefahaman tentang apa yang berlaku. Sejarah adalah cabang ilmu yang mengkaji secara sistematis keseluruhan perkembangan proses perubahan dan dinamika kehidupan masyarakat dengan segala aspek kehidupannya yang terjadi di masa lampau (Sardiman, 2003: 9).

Pembelajaran sejarah adalah proses interaksi antara siswa dengan lingkungannya, sehingga terjadi perubahan tingkah laku akibat dari interaksinya dengan mempelajari sejarah. Pembelajaran sejarah tidak hanya menghafal dan mengenang peristiwa-peristiwa sejarah yang telah lalu saja. Tetapi pembelajaran sejarah mempunyai tujuan agar siswa mampu 
mengembangkan kompetensi untuk berpikir secara kronologi dan memiliki pengetahuan masa lampau untuk dapat memahami dan menjelaskan proses perkembangan dan perubahan masyarakat dengan keanekaragaman sosial budaya dalam rangka.

Model Pembelajaran Living History merupakan model pembelajaran sejarah yang bersumber pada lingkungan kehidupan sekitar siswa. Model Pembelajaran Living History membimbing peserta didik dalam melakukan penelusuran peristiwa sejarah yang terdapat di lingkungan sekitarnya, tempat peserta didik menjalani kehidupan kesehariannya (Rudy Gunawan, 2011: 183). Pada prinsipnya model living history merupakan implementasi dari penelitian sejarah sehingga peserta didik mampu untuk mengkaji sejarah dan bagaimana menuliskan sejarah tersebut melalui teknik penelitian sejarah.

Nasionalisme merupakan sebuah cita-cita yang ingin menberi batas antara "kita yang sebangsa " dengan mereka dari bangsa lain, antara "negara kita" dan negara mereka (Abdullah, 2001: 47).Menurut Aman (2011:141) dalam bukunya mengemukakan bahwa ada beberapa indikator sikap nasionalisme yaitu, bangga sebagai bangsa Indonesia, cinta tanah air dan bangsa, rela berkorban demi bangsa, menerima kemajemukan, bangga pada budaya yang beragam, menghargai jasa para pahlawan, mengutamakan kepentingan umum.

\section{Pembelajaran Sejarah}

Pembelajaran sejarah merupakan cabang ilmu pengetahuan yang menelaah tentang asal-usul dan perkembangan serta penanan maasyarakat pada masa lampau yang mengandung nilai-nilai kearifan yang dapat digunakan untuk melatih kecerdasan membentuk sikap, watak dan kepribadian peserta didik. Heri Susanto (2014) Pendidikan sebagai proses pembudayaan terus mengalami perkembangan, baik dari segi sistem, pola, materi maupun strategi paedagogik pembelajaran. Dalam perkembangan tersebut seringkali terdapat banyak pengaruh dari berbagai tren yang berkembang dimasyarakat, bangsa dan Negara. Dalam konteks ini pendidikan adalah proses bembudayaan yang sangat dinamis dan selalu menyesuaikan diri dengan jiwa zamannya. (Sapriya, 2012:209-210). Pembelajaran sejarah berfungsi untuk menyadarkan peserta didik akan adanya proses perubahan dan perkembangan masyarakat dalam dimensi waktu dan untuk membangun perspektif serta kesadaran sejarah dalam menemukan, memahami, dan menjelaskan jati diri bangsa di masa lalu, masa kini, dan masa depan di tengah-tengah perubahan dunia (Depdiknas, 2003:6). Pembelajaran sejarah juga merupakan cara untuk membentuk sikap sosial. Adapun sikap sosial tersebut antara lain: saling 
menghormati, menghargai perbedaan, toleransi dan kesediaan untuk hidup berdampingan dalam nuansa multikulturalisme (Susanto, 2014:62).

Pembelajaran sejarah memiliki peran yang sangat penting di dalam pembentukan watak, sikap dan perkembangan bangsa yang bermakna dalam pembentukan bangsa Indonesia yang memiliki rasa kebangsaan, intelektual, menghargai perjuangan bangsanya dan rasa nasionalisme. Menurut Sapriya (2012:209) pembelajaran sejarah memiliki cakupan materi sebagai berikut: (1) mengandung nilai-nilai kepahlawanan, keteladanan, kepeloporan, patriotisme, nasionalisme, dan semangat pantang menyerah yang mendasari proses pembentukan watak dan kepribadian peserta didik; (2) memuat khasanah mengenai peradaban bangsa-bangsa termasuk peradaban bangsa Indonesia; (3) menanamkan kesadaran persatuan dan persaudaraan serta solidaritas untuk menjadi pemersatu bangsa dalam menghadapi ancaman disintegrasi; (4) memuat ajaran moral dan kearifan yang berguna dalam mengatasi krisis multidimensi yang dihadapi dalam kehidupan sehari-hari; (5) menanamkan dan mengembangkan sikap bertanggung jawab dalam memelihara keseimbangan dan kelestarian lingkungan hidup.Peran penting pembelajaran sejarah bukan hanya sebagai proses transfer ide, akan tetapi juga proses pendewasaan peserta didik untuk memahami identitas, jati diri dan kepribadian bangsa melalui pemahaman terhadap peristiwa sejarah. Menurut Heri Susanto seputar pembelajaran sejarah ( 2014 ) Pembelajaran sejarah seharusnya dapat menjadi suatu pembelajaran yang imajinatif yang akan mempunyai banyak manfaat dalam kehidupan berbangsa. Pembelajaran sejarah seharusnya mampu menjadi pengikat konstruksi nasionalisme bangsa Indonesia. Bukan sekedar menghapalkan fakta, pembelajaran sejarah pada mengembangkan budaya unggul sebagai sebuah bangsa yang bermartabat.

Menurut Kochhar (2008:27-37) tujuan pembelajaran sejarah adalah sebagai berikut:

1. mengembangkan pemahaman tentang diri sendiri.

2. memberikan gambaran yang tepat tentang konsep waktu, ruang dan masyarakat.

3. membuat peserta didik mampu mengevaluasi nilai dan hasil yang dicapai generasinya.

4. mengajarkan toleransi.

5. memperluas cakrawala intelektualitas.

6. mengajarakan prinsip-prinsip moral.

7. menanamkan orientasi ke masa depan. 
8. melatih peserta didik menangani isu-isu kontroversial.

9. membantu memberikan jalan keluar bagi berbagai masalah sosial dan perorangan.

10. memperkokoh rasa nasionalisme.

11. mengembangkan pemahaman internasional.

12. mengembangkan keterampilan-keterampilan yang berguna.

\section{Model living history dalam pembelajaran sejarah}

History mendorong peserta didik untuk lebih peka terhadap lingkungan. Selain itu terdorong mengembangkan keterampilan-keterampilan proses yang bersifat discovery dan inquiry, seperti mengobservasi, melaksanakan wawancara, menyeleksi bahan/sumber sejarah, mengklasifikasi, menemukan sesuatu, bahkan dalam menggeneralisasi. Model Living Historyjuga mengajak peserta didik untuk melakukan kegiatan lawatan ke tempat-tempat bersejarah. Lawatan sejarah, setidak-tidaknya, memiliki 3 aspek yang sifatnya mendidik: rekreatif, inspiratif, dan edukatif. Model ini juga dapat menggerakkan sikap dan perilaku yang bertitik tekan pada nilai sejarah, seperti nilai cinta tanah air, rela berkorban, solidaritas, dan semangat persatuan. Robert Douch lewat salah satu bukunya yang berjudul Local History and The Teacher menyatakan bahwa dalam pembelajaran sejarah, hendaknya peserta didik dapat melihat langsung kehidupan yang nyata, bukan materi pelajaran yang abstrak. Untuk mencapai aspirasi ini, pembelajaran sejarah dapat bersumber dari pengalaman kehidupan siswa seharihari. Kedekatan emosional siswa dengan lingkungannya merupakan sumber belajar yang berharga bagi terjadinya proses pembelajaran di kelas (Mulyana dan Gunawan, 2007: 1). Sumber pembelajaran berupa aspek lingkungan sekitar (neighborhood) merupakan batasan keruangan terpenting dalam studi kesejarahan, khususnya sejarah lokal. Lingkungan sekitar yang terbatas, mulai dari lingkungan keluarga hingga meluas ke lingkuaran sejarah. Dinamika pengalaman hidup siswa di keluarganya juga dapat menjadi inspirasi bagi pembelajaran sejarah di sekolah (Mulyana dan Gunawan, 2007: 2-3). Sebagaimana yang telah diutarakan David D. Van Tassel dalam Agus M. dan Restu G. (2007: 7), penulisan dan pengkajian sejarah dewasa ini tidak lagi menekankan soal kelompok elite sosial tertentu. Fokus baru dalam studi ini antara lain kelompok-kelompok sosial keluarga, aneka permasalahan sosial, pabrik dan perusahaan, kelahiran dan kematian, masa kanak-kanak dan masa tua, kriminalitas serta penyakit kejiwaan. 
Materi sejarah yang disajikan dapat diambil dari lingkungan terdekat peserta didik, mulai dari kehidupan di rumah hingga di luar rumahnya seperti lingkungan komunitas masyarakat dimana peserta didik berada. Materi yang diajarkan tetap memperhatikan konsep-konsep ilmu yang dapat dikembangkan dalam sejarah. Sudah barang tentu konsep-konsep ilmu disajikan dengan menyesuaikan tingkat perkembangan psikologi siswa. Umumnya anak sekolah lebih mudah memahami konsep-konsep tersebut dalam tingkat yang lebih konkrit alias tidak diperkenalkan secara abstrak (Agus M. dan Restu G., 2007: 7). Penyajian konsep-konsep yang lebih konkrit terasa kian penting mengingat kegiatan belajar mengajar yang terbaik memang harus menumbuhkembangkan unsur kognitif, afektif, dan psikomotor peserta didik secara optimal. Pembelajaran yang baik juga mentransformasikan ketiga unsur tersebut melalui metode yang efektif dan tidak saja berfaedah dalam pandangan guru, melainkan juga terasa manfaatnya bagi kehidupan kekinian (now) dan kedisinian (here) menurut sudut pandang peserta didik. Tujuan akhirnya, pembelajaran berkontribusi signifikan dalam membantu mengarahkan laju kehidupan masa kini dan masa depan peserta didik ke arah yang lebih baik. Wawan Darmawan, S.Pd., M.Hum dalam Agus M. dan Restu G. (2007: 245) mengutip pendapat Douch (1967) yang menawarkan tiga cara untuk mengaplikasikan model pembelajaran Living History dalam pengajaran sejarah lokal di sekolah. Pertama, mengambil contoh-contoh dari kejadian lokal untuk memberi ilustrasi yang lebih hidup dari uraian sejarah nasional maupun sejarah dunia yang sedang diajarkan. Di sini sudah jelas tidak akan ada masalah bagi usaha mengkaitkan sejarah lokal dengan kurikulum pengajaran sejarah yangberlaku, misalnya dalam peristiwa sejarah lokal Geger Cilegon 1888. Selain menjelaskan peristiwa yang terjadi dalam lingkup nasional, guru juga harus memberikan gambaranbagaimana daerah di lingkungan sekitarnya pada periode itu.

\section{Pembelajaran Sejarah dan nasionalisme}

Peranan sejarah sangat penting bagi kehidupan masyarakat Indonesia, terutama dalam lingkungan sekolah. Untuk itu, pembelajaran sejarah diajarkan mulai dari sejak dini, dari SD, SMP, SMA, hingga perguruan tinggi. Pembelajaran sejarah ini juga membantu manusia untuk menyelesaikan berbagai masalah dan membekali masa depan yang cerah dengan melihat dari masa lalu. MateriMateri sejarah mengandung nilai-nilai kepahlawanan,keteladanan, kepeloporan, patriotisme, nasionalisme, dan semangat pantang menyerah yang mendasari proses pembentukan watak dan kepribadian peserta didik; memuat khasanah mengenai peradaban bangsa-bangsa, termasuk peradaban bangsa Indonesia. Materi tersebut merupakan bahan pendidikan yang mendasar bagi proses pembentukan dan penciptaan peradaban bangsa 
Indonesia di masa depan menanamkan kesadaran persatuan dan persaudaraan serta solidaritas untuk menjadi perekat bangsa dalam menghadapi ancaman disintegrasi bangsa syarat dengan ajaran moral dan kearifan yang berguna dalam mengatasi krisis multidimensi yang dihadapi dalam kehidupan sehari-hari; dan berguna untuk menanamkan dan mengembangkan sikap bertanggung jawab dalam memelihara keseimbangan dan kelestarian lingkungan hidup (Aman, 2011:34).

Nasionalisme merupakan sebuah cita-cita yang ingin menberi batas antara "kita yang sebangsa" dengan mereka dari bangsa lain, antara "negara kita" dan negara mereka (Abdullah, 2001: 47).Menurut Aman (2011:141) dalam bukunya mengemukakan bahwa ada beberapa indikator sikap nasionalisme yaitu, bangga sebagai bangsa Indonesia, cinta tanah air dan bangsa, rela berkorban demi bangsa, menerima kemajemukan, bangga pada budaya yang beragam, menghargai jasa para pahlawan, mengutamakan kepentingan umum.Dewasa ini, siswa SMA seringkali melupakan hal-hal penting seperti rasa bangga terhadap bangsa dan negaranya, kurang tahu makna na-sionalisme, dan etnosentrisme. Banyak hal lain yang seringkali dilalaikan bahkan diabaikan, kemudian justru hal tersebut menjadi unsur lunturnya sikap Nasionalisme. Seringkali mereka lebih bangga terhadap produk di luar daerah atau wilayah tempat ia berasal, jarang menonton tayangan kenegaraan seperti tayan-gan berita. Banyaknya perilaku yang mereka lakukan seperti halnya, membolos di saat jam pelajaran, tidak mengikuti upacara, dan kurang menyukai lagu-lagu nasional. Mulai dari hal tersebutlah yang menjadikan sikap nasional-isme mereka memudar. Sehingga mengakibatkan masalah tersendiri bagi negara ini. Menurut Djoko Suryo (2005: 3) (dalam Aman 2011: 62) merumuskan beberapa indikator terkait dengan pembelajaran sejarah tersebut yaitu :

1 pembelajaran sejarah memiliki tujuan, substansi, dan sasaran pada segi-segi yang bersifat normatif.

2. nilai dan makna sejarah diarahkan pada kepentingan tujuan pendidikan daripada akademik atau ilmiah murni.

3. aplikasi pembelajaran sejarah bersifat pragmatik, sehingga dimensi dan substansi dipilih dan disesuaikan dengan tujuan, makna, dan nilai pendidikan yang hendak dicapai yakni sesuai dengan tujuan pendidikan.

4. pembelajaran sejarah secara normatif harus relevan dengan rumusan tujuan pendidikan nasional. 
5. pembelajaran sejarah harus memuat unsur pokok: instruction, intellectual training, dan bertanggung jawab pada masa depan bangsa.

6. pembelajaran sejarah tidak hanya menyajikan pengetahuan fakta pengalaman kolektif dari masa lampau, tetapi harus memberikan latihan berpikir kritis dalam memetik makna dan nilai dari peristiwa sejarah yang dipelajarinya.

Pendidikan sejarah, selain bertugas memberikan pengetahuan sejarah (kognitif), tetapi juga untuk mengenalkan nilai-nilai luhur bangsanya (afektif). Pendidikan sejarah akan mampu menumbuhkan sikap nasionalisme apabila diselenggarakan mengacu pada upaya pencapaian tujuan kurikulum yang salah satunya adalah pembentukan sikap nasionalisme. Oleh karena itu, legalitas pendidikan sejarah dalam kurikulum pendidikan nasional harus menekankan aspekaspek penting materi pelajaran sejarah, dimana kurikulum harus menekankan: pentingnya pembelajaran sejarah sebagai sarana pendidikan bangsa; sebagai sarana pembangunan bangsa secara mendasar menanamkan national consciousness dan Indonesian-hood sebagai sarana menanamkan semangat nasionalisme; perspektif sejarah the past-present-future sebagai sarana menanamkan semangat nasionalisme; historical consciousness pada masa revolusi kemerdekaan; membentuk semangat nasionalisme; dan rumusan sejarah sebagai mata pelajaran yang menanamkan pengetahuan dan nilai-nilai proses perubahan dan perkembangan masyarakat Indonesia dan dunia dari masa lalu hingga masa kini (Djoko Suryo, 2005: 2) (dalam Aman, 2011: 43). Adapun sasaran umum pembelajaran sejarah dalah sebagai berikut: 1) mengembangkan pemahaman tentang diri sendiri, 2memberikan gambaran yang tepat tentang konsep waktu, ruang, dan masyarakat, 3) membuat masyarakat mengetahui nilai-nilai dan hasil yang telah dicapai oleh generasinya, 4) mengajarkan toleransi, 5) memperkokoh rasa nasionalisme (Kochhar, 2008: 27-35). Realitas yang selama ini terjadi, para pendidik hanya berkonsentrasi pada diseminasi materi tanpa mempertimbangkan bagaimana proses tersebut mempengaruhi peserta didik dan membentuk lingkungan pembelajaran. (Caroline Rekar Murno, 2005) (dalamAman, 2011: 76). Kebanyakan pendidik juga lebih mengutamakan nilai kognitif yang harus dicapai oleh siswa didiknya. Sedangkan nilai afektifnya seperti nasionalisme seringkali tak terhiraukan. Sifat-sifat yang berkaitan dengan penanaman nilai moral pun mulai memudar. Seringkali siswa didik setelah melakukan pembelajaran justru bersikap yang tidak sewajarnya atau kurang baik. Jadi pembelajaran yang seharusnya mendidik siswa didik untuk bertingkah laku lebih baik dan mempunyai sikap nasionalisme belum bisa terlaksana sepenuhnya. Heri Susanto (2017) dalam jurnal, Pemahaman Sejarah Daerah dan Persepsi Terhadap Keberagaman Budaya dalam Membina Sikap Nasionalisme (Studi Korelasi 
pada Mahasiswa Pendidikan Sejarah FKIP UNLAM) adanya hubungan positif yang signifikan antara pemahaman sejarah daerah dan persepsi terhadap keberagaman budaya dengan sikap nasionalisme mahasiswa. Hal tersebut membawa implikasi bahwa pembinaan sikap nasionalisme dikalangan mahasiswa Program Studi Pendidikan Sejarah seyogyanya dilakukan dengan memperkuat pemahaman sejarah daerah terutama sejarah perjuangan di daerah dan menanamkan persepsi positif terhadap keberagaman budaya bangsa.

\section{Penutup}

Pembelajaran sejarah dalam menanamkan sikap nasionalisme dengan model pembelajaran Living History dalam kegiatan belajar di mana dalam model living history merupakan model pembelajaran mendorong keterampilan yang bersifat discovery dimana hal tersebut sangat membantu menumbuhkan sikap nasionalisme pada peserta didik. Model Living History juga mengajak peserta didik untuk melakukan kegiatan lawatan ke tempat-tempat bersejarah. Lawatan sejarah, setidak-tidaknya, memiliki 3 aspek yang sifatnya mendidik: rekreatif, inspiratif, dan edukatif. Model ini juga dapat menggerakkan sikap dan perilaku yang bertitik tekan pada nilai sejarah, seperti nilai cinta tanah air, rela berkorban, solidaritas, dan semangat persatuan.

\section{Daftar pustaka}

Abdullah, Taufik. 2001. Nasionalisme Dan Sejarah. Bandung: CV. Satya Histori-ka.

Aman. 2011. Model Evaluasi Pembelajaran Sejarah. Yogyakarta: Ombak.

Amri, Sofan dan Iif Khoiru Ahmasi. 2010. Konstruksi Pengembangan Pembelajaran.

Jakarta: Prestasi Pustaka.

Kochhar, S.K. 2008. Pembelajaran Sejarah (Teaching Of History). Jakarta: PT Grasindo.

Sukmadinata, N. S. 2007. Pengembangan Ku-rikulum Teori dan Praktek. Bandung: PT Remaja Rosdakarya. 
Kasmadi, Hartono. 1996. Model-model dalam Pengajaran Sejarah. Semarang: Ikip Semarang Press.

Dyah Kumalasari. 2003. Hidden Curriculum Dalam Pengajaran Sejarah Dan Pembentukan Jiwa Nasionalisme, Yogyakarta: Universitas Negeri Yogyakarta.

Hasan, S.H. (2011). Pendidikan Sejarah Untuk Memperkuat Pendidikan Karakter, Makalah dikemukakan pada Seminar Sejarah Nasional Himpunan Mahasiswa Sejarah, UNNES, 10 Nopember 2011.

Heri Susanto ( 2017 ) Pemahaman Sejarah Daerah dan Persepsi Terhadap Keberagaman Budaya dalam Membina Sikap Nasionalisme (Studi Korelasi pada Mahasiswa Pendidikan Sejarah FKIP UNLAM)

Heri Susanto ( 2014 ) seputar pembelajaran sejarah, isu, gagasan dan strategi pembelajaran. 